\title{
Lymphocyte dysmetabolism: an immunocytochemical comparative approach in IDDM and control subjects
}

\author{
A. Pugnaloni' ${ }^{1}$ G.L. Sgarbi ${ }^{2}$, M. Tesei ${ }^{1}$, M. D’Aurelio², G. Ragni ${ }^{3}$, G. Parenti Castelli ${ }^{2}$, S. Salardi $^{3}$, \\ S. Zucchini ${ }^{3}$, C. Bovina ${ }^{2}$, E. Cacciari ${ }^{3}$, G. Lenaz ${ }^{2}$, and G. Biagini ${ }^{1}$
}

${ }^{1}$ Inst. of Human Morphology-Histology, University of Ancona, Italy; ${ }^{2}$ Dept. of Biochemistry and ${ }^{3}$ Inst. of Clinical Pediatrics, University of Bologna, Italy

Accepted: 28/07/00

Key words: IDDM, phosphotyrosine, immuno-electron microscopy, NADH oxidoreductase

\section{SUMMARY}

We have investigated by immuno-electron microscopy the presence of phosphotyrosine in cells as a whole and in different cell districts (nucleus, cytoplasm, plasma membrane, and mitochondria) in peripheral blood lymphocytes of IDDM (insulindependent diabetes mellitns) patients and agematched controls.

Immuno-gold particle density was highest in mitochondria and decreased in cytoplasm, nucleus and plasma membrane. The time dependence of phosphotyrosine labelling after cell isolation was very strong in all subcellular populations, with a fall in immunogold staining after $30 \mathrm{~min}$.

Staining levels at zero time were similar in controls and IDDM patients; the loss of phosphotyrosine labelling was much stronger in controls, except in the plasma membrane.

Plasma membrane NADH oxidoreductase activity, studied using cytosolic NADH as substrate and assayed with DCIP as acceptor, was significantly reduced in IDDM patients, suggesting a response to a deficient mitochondrial energetic activity.

The fact that NADH oxidoreductase is a growth factor related to tyrosine phosphorylation pathways raises intriguing questions on the cellular derangement occurring in peripheral lymphocytes in IDDM, although the relationships among the immunocytochemical and biochemical changes is still obscure.

\section{INTRODUCTION}

It is well documented that several metabolic dysfunctions are present in hyperglycemic conditions; the mechanisms underlying such metabolic complications of hyperglycemia are not, however, completely clear. Experimental diabetes seems to be able to cause the loss of more than $95 \%$ of mitochondrial trancriptional capacity (Kristal et al. 1997) and several data indicate that in the hepatocytes of diabetic animals the production of reactive oxygen species in mitochondria is strongly stimulated (Karagezian et al. 1990; Goldkorn et al. 1998). On the other hand, oxidation products occurring in diabetes may be involved in subtoxic processes at the level of signal transduction: indeed, several oxidants stimulate tyrosine as well as serine/threonine phosphorylation (Pugnaloni $e t$ al. 1999, Goldkorn et al. 1998; Clerk et al. 1998; Bize et al. 1998), which is known to be a key step in signal transduction processes. 
Several factors are involved in the pathological consequences of diabetic hyperglycemia: among those are oxidative stress, the direct toxic effect of increased glucose levels, and the bioenergetic deficits occurring as a consequence of the metabolic derangement.

In particular, among other consequences, it is known that oxidative stress promotes an accumulation of intramitochondrial $\mathrm{Ca}^{2+}$ which determines, or contributes to, the production of mitochondrial DNA damage (Low et al. 1997; Cobo et al. 1997).

Altered $\mathrm{Ca}^{2+}$ homeostasis and impaired gene expression patterns may play a crucial role in the clinical onset of several diseases, and various mitochondrial dysfunctions can have their key factors in lowered electron transport rate and low mitochondrial energy coupling (Olson et al. 1998 Crane et al. 1994; Matsuoka et al. 1997; Guidarelli et al. 1997).

Defective mitochondrial electron transfer enhances the NADH/NAD+ cytoplasmic ratio, an event that has important metabolic consequences, first of all an increased lactate production; the importance of the pyridine nucleotide redox equilibrium in relation to diabetes is even clearer if one considers that reduced redox capacity has been reported in the mitochondria of glucose-stimulated Langerhans islets (Matschinnsky 1996; Ramirez et al. 1996). Moreover, glucose-stimulated insulin release has been seen to stimulate in turn mitochondrial dehydrogenase activity and translocation of $\mathrm{Ca}^{2+}$ from mitochondrion to cytosol (Ramirez et al. 1995; Moran et al. 1997; Salceda et al. 1998).

The aim of the present work was to assess quantitatively by an immuno-electron microscopic study the presence of phosphorylated tyrosine in the nucleus, cytoplasm, mitochondria and cell membrane (in parallel with cell membrane NADH oxidase activity, a cell membrane redox marker) in lymphocytes from IDDM patients and norma individuals in order to seek possible relationships with the glycemic status.

Given the firm evidence for mitochondrial alterations in IDDM lymphocytes (Vidal et al. 1997 Novials et al. 1997), the present study of diabetic patients was performed in an easily accessible cel population, i.e. peripheral blood lymphocytes, which are considered a useful tool to monitor IDDM disease behaviour, to obtain crucial data on the energy status of the immunological compartment, as well as to monitor the parameters related to ischemia and abnormal blood viscosity (Morigi et al. 1998; Ceriello et al. 1998; Victor et al. 1985), which are closely connected with the function and metabolic derangement of IDDM.

\section{MATERIALS AND METHODS}

\section{Materials}

Monoclonal anti-phosphotyrosine antibody (4G10) was purchesed from UBI (Lake Placid, NY), 12-nm gold particle-conjugated secondary antibody from Jackson Immuno Research (West Grove, PA), and L.R. White embedding resin from Polyscience (Warrington, PA).

All the other reagents were of molecular or analytical grade.

\section{Patients and Methods}

Lymphocytes were obtained by centrifugation from $40 \mathrm{ml}$ of peripheral venous blood drawn from 11 IDDM patients and 9 healthy controls aged 5 to 19 years who gave their informed consent to participate in the study. Lymphocytes were divided into two aliquots: one was used immediately $\left(\mathrm{T}^{\circ}\right)$ and the other after $30 \mathrm{~min}$ at $4^{\circ} \mathrm{C}\left(\mathrm{T}^{30}\right)$ for parallel biochemical and immunomorphological studies.

Owing to the need for testing blood samples of at least $40 \mathrm{ml}$ and to the compromised state of some patients, in 4 cases the same lymphocyte aliquots were studied for both series of experiments (Table 1).

\section{a- Morphology and Immunocytochemistry}

For the morphological study, pellets of lymphocytes were fixed in $1 \%$ glutaraldehyde in $0.1 \mathrm{M}$ phosphate buffer (PB) for $1 \mathrm{~h}$ at $4^{\circ} \mathrm{C}$, washed overnight in $0.15 \mathrm{M} \mathrm{PB}$, dehydrated in ethanol and embedded in resin. Ultrathin sections $(90 \mathrm{~nm})$ were cut and mounted on nickel grids. The immunocytochemical study of tyrosine phosphorylation (Alessandro et al. 1997; Pugnaloni et al. 1999) was performed on post-embedded material using a primary anti-phosphotyrosine monoclonal antibody, 4G10, (1:100) in Tris-HCl (50 mM Tris, $0.14 \mathrm{M} \mathrm{NaCl}, \mathrm{pH} 7.6$ ) containing $0.1 \%$ bovine serum albumin (BSA). Sections were then washed and incubated with goat anti-mouse (GAM)IgG conjugated with $12-\mathrm{nm}$ colloidal gold particles $(1: 10)$ in $20 \mathrm{mM}$ Tris- $\mathrm{HCl}, \mathrm{pH} 8.2$, containing $0.1 \%$ BSA for $1 \mathrm{~h}$ at room temperature. Samples not incubated with the primary antibody were 
Table I

Lymphocytes from control subjects and from IDDM patients: evaluation of phosphotyrosine expression (4G10 MoAb 1:100. No gold particles/ $\left(\mathrm{mm}^{2} \mathrm{o}\left(\mathrm{mm}^{*}\right)\right.$ in cells used at $\mathrm{T}^{0}$ and $\mathrm{T}^{30}$ (mean values $\pm \mathrm{sd}$ )

\begin{tabular}{lccccc}
\hline Cases & Cytoplasm & Nucleus & $\begin{array}{c}\text { Total Cell } \\
\text { Labelling }\end{array}$ & $\begin{array}{c}\text { Cell } \\
\text { Membrane* }\end{array}$ & Mitochondria \\
\hline $\begin{array}{l}\text { Control subjects } \\
\mathrm{T}^{0}\end{array}$ & $10.07 \pm 5.80$ & $5.33 \pm 4.15$ & $8.31 \pm 5.01$ & $1.33 \pm 1.01$ & $19.03 \pm 10.86$ \\
$\begin{array}{l}\text { Control subjects } \\
\mathrm{T}^{30}\end{array}$ & $4.59 \pm 2.32$ & $2.38 \pm 2.19$ & $3.45 \pm 1.78$ & $0.93 \pm 0.48$ & $5.79 \pm 3.04 * *$ \\
$\mathrm{IDDM}^{\mathrm{ND}}$ patients & $9.68 \pm 5.74$ & $5.34 \pm 5.20$ & $8.72 \pm 7.23$ & $1.97 \pm 3.76$ & $17.34 \pm 12.89$ \\
$\mathrm{~T}^{0}$ & $6.50 \pm 4.73$ & $3.49 \pm 2.56$ & $5.25 \pm 3.41$ & $0.89 \pm 0.42$ & $13.08 \pm 15.02$ \\
$\mathrm{IDDM}^{30}$ patients & & & & & \\
\hline
\end{tabular}

$* * \mathrm{p}<0.05-$ Mann Whitney U test

used as controls and did not stain (data not shown). Grids were counterstained with aqueous uranyl acetate and lead citrate.

\section{Morphometric evaluations}

Specimens were observed and photographed using a Philips CM10 (Eindhoven, The Netherlands) transmission electron microscope at $80 \mathrm{KW}$. For each sample, 20 images at 18,000X magnification which included membrane, cytoplasm and nucleus were selected and evaluated with an image analyser (Lucia-Nikon, Italy) using an interactive software. Gold-particle density was expressed as absolute density, i.e. as the number of gold particles counted per $\mu \mathrm{m}^{2}$ or $\mu \mathrm{m}$ in different cellular districts (cytoplasm, nucleus, mitochondria and cell membrane), or as total cell labelling per $\mu \mathrm{m}^{2}$ of total cell surface. In the case of mitochondria, labelling density was referred to the total mitochondrial area of each cell. Data distribution was assessed and is shown graphically in Fig. 3. Because of the high standard deviation (sd) values observed in all cellular districts (mainly in mitochondria), statistical evaluations were performed using the Mann Whitney U non-parametric test.

\section{b-Biochemistry. Plasma membrane NADH oxi- dase}

Intact lymphocytes from both IDDM patients and controls were used for this study. Plasma membrane oxidoreductase activity was assayed using either ferricyanide $\left(\mathrm{K}_{3} \mathrm{Fe}(\mathrm{CN})_{6}\right)$ or dichlorophenol indophenol (DCIP) as acceptors (Vaillant et al. 1996). The electron donor under the conditions used was endogenous NADH. The activity was assayed in the presence of mitochondrial inhibitors to avoid possible interference with mitochondrial oxidative activities.

For NADH-ferricyanide reductase activity 0.5$1 \cdot 10^{6}$ cells were washed in $500 \mu \mathrm{l}$ phosphate buffer saline (PBS) $\left(0.15 \mathrm{M} \mathrm{NaCl}, 20 \mathrm{mM} \mathrm{Na} 2 \mathrm{HPO} 4 \cdot \mathrm{H}_{2} 0\right.$, $\mathrm{pH}$ 7.4) and $2 \mathrm{mM} \mathrm{KCN}, \mathrm{pH} 7.4$, and resuspended in $1 \mathrm{ml}$ PBS containing $10 \mathrm{mM}$ glucose, $1 \mathrm{mM}$ pyruvate, $1 \mu \mathrm{g} / \mathrm{ml}$ rotenone, $1 \mathrm{~g} / \mathrm{ml}$ antimycin $\mathrm{A}, 1 \mu \mathrm{g} / \mathrm{ml}$ myxothiazol, $2 \mathrm{mM} \mathrm{KCN}$, for $10 \mathrm{~min}$ at $37^{\circ} \mathrm{C}$. Cells were then added to $1.5 \mathrm{ml}$ reaction mixture containing PBS $\left(\mathrm{NaCl} 0,15 \mathrm{M}, 20 \mathrm{mM} \mathrm{Na} 2 \mathrm{HPO}_{4} \cdot \mathrm{H}_{2} \mathrm{O}_{2}\right)$, $\mathrm{KCN} 2 \mathrm{mM}, \mathrm{pH} 7.4$ and $250 \mu \mathrm{M} \mathrm{K} \mathrm{K}_{3} \mathrm{Fe}(\mathrm{CN})_{6}$.

Ferricyanide reduction was followed at 420-500 nm by SIGMA-ZWS II Zweiwellenlaengen-spectral photometer, for $4 \mathrm{~min}$ at $37^{\circ} \mathrm{C}$; the molar extinction coefficient used was of $1,000 \mathrm{M}-1 \mathrm{~cm}-1$.

For NADH-DCIP reductase activity, cells treated as above were added to $1.5 \mathrm{ml} \mathrm{PBS}$ reaction mixture containing $2 \mathrm{mM} \mathrm{KCN}, \mathrm{pH} 7.4$ and $20 \mu \mathrm{M}$ DCIP. In this case, DCIP reduction was monitored at $600-700 \mathrm{~nm}$ for $2 \mathrm{~min}$; the molar extinction coefficient used was $21 \mathrm{mM}^{-1} \mathrm{~cm}^{-1}$.

\section{RESULTS}

Morphological and immunocytochemical evaluations

Controls: $\mathrm{T}^{0}$ (Fig. 1, a). At $\mathrm{T}^{0}$, values were fairly inhomogeneous, with high sd, although they never exceeded the mean values. This finding could be related to the inhomogeneity of the lymphocyte pop- 
Fig. 1 - Immunoelectron microscopy of phosphotyrosine in isolated control lymphocytes prepared as described in Materials and Methods. Ultrathin sections were incubated with antiphosphotyrosine and detected with immunogold reagent. Transmission electron micrographs were taken at 39,500X final magnification. $\mathrm{M}=$ mitocondria. a) Control control cells at $\mathrm{T}^{30}$.

ulation itself and therefore to the different expression of phosphorylated tyrosine by the different types of lymphocytes. The numerical density of gold particles per $\mathrm{m} 2$ was $10.07 \pm 5.80$ in the cytoplasmic district,
$5.33 \pm 4.15$ in the nucleus, $19.03 \pm 10.86$ in mitochondria and $8.31 \pm 5.01$ on the whole cell surface. At the level of the plasma membrane, numerical density per $\mathrm{m}$ of membrane length was $1.33 \pm 1.01$. 


\section{Table II}

Lymphocytes from control subjects and from IDDM patients: evaluation of phosphotyrosine expression (4G10 MoAb 1:100. No gold particles $/ \mathrm{mm}^{2}$ or $\left(\mathrm{mm}^{*}\right)$ after $30 \mathrm{~min}$. Values are expressed as percent of $\mathrm{T}^{0}$ condition (mean values $\pm \mathrm{sd}$ )

\begin{tabular}{lccccc}
\hline Cases & Cytoplasm & Nucleus & $\begin{array}{c}\text { Total Cell } \\
\text { Labelling }\end{array}$ & $\begin{array}{c}\text { Cell } \\
\text { Membrane* }\end{array}$ & Mitochondria \\
\hline Control subjects & 42.90 & 44.65 & 41.52 & 69.92 & 30.42 \\
IDDM patients & 60.74 & 65.48 & 63.18 & 66.92 & 68.73 \\
\hline
\end{tabular}

Controls: $\mathrm{T}^{30}$ (Fig. 1, b). Thirty minutes after collection, values decreased in all cytoplasmic districts: gold-particle density per $\mu \mathrm{m}^{2}$ was $4.59+2.32$ in the cytoplasm $\left(42.90 \%\right.$ of $\left.\mathrm{T}^{0}\right), 2.38 \pm 2.19$ in the nucleus $(44.65 \%), 5.79 \pm 3.04$ in mitochondria $(30.42 \%)$, and $3.45 \pm 1.78$ on the whole cell surface $(41.52 \%)$; finally, in the plasmalemma, numerical density per $m$ of membrane was $0.93 \pm 0.48\left(69.92 \%\right.$ of $\left.\mathrm{T}^{0}\right)$.

IDDM: $\mathrm{T}^{0}$ (Fig. 2a). In IDDM patients, values were also inhomogeneous with high sd in the same cell districts: cytoplasm $(9.68 \pm 5.74)$, nucleus $(5.34 \pm 5.20)$, mitochondria (17.34 \pm 12.89$)$, total cell surface (8.72 $\pm 7.23)$ and cell membrane $(1.97 \pm 3.76)$.

IDDM: $\mathrm{T}^{30}$ (Fig. 2,b). Also in this case, values decreased from $\mathrm{T}^{0}$ to $\mathrm{T}^{30}$. Mean labelling and percent labelling reductions were, respectively, $6.50 \pm 4.73$ and $60.74 \%$ in the cytoplasm, $3.49 \pm 2.56$ and $65.48 \%$ in the nucleus, $13.08 \pm 15.02$ and $68.73 \%$ in mitochondria, $5.25 \pm 3.41$ and $63.18 \%$ on total cell surface and $0.89 \pm 0.42$ and $66.92 \%$ in the plasmalemma. The reduction in phosphotyrosine expression was thus less rapid in the lymphocytes of IDDM patients. This was especially evident in mitochondria, even though values were less homogeneous.

In the mitochondria, significant differences $(\mathrm{p}<0.05)$ were found between the lymphocytes of control and diabetic subjects at $\mathrm{T}^{0}$ and $\mathrm{T}^{30}$, respectively. In this cellular district, control subjects at $\mathrm{T}^{30}$ showed a numeri- cal density of $5.79 \pm 3.04$ per $\mu^{2}$, with a $30.42 \%$ reduction with respect to $\mathrm{T}^{0}$.

The trend of phosphorylation in the different conditions was represented with a diagram (Fig. 3), and mean values, with the corresponding sd, were calculated for the various samples to evidence their homogeneity or lack of it (see Materials and Methods).

\section{Biochemical Aspects of Plasma Membrane} NADH-oxidase activity (Table III)

An increase in NADH $\rightarrow$ DCIP activity $(p<0.005)$, index of a higher redox potential inside cells, was observed in patients $\left(2.69 \pm 0.59 \mathrm{nmol} \cdot \mathrm{min}^{-1} \cdot 10^{-6}\right.$ cells) with respect to controls $\left(1.97 \pm 0.51 \mathrm{nmol} \cdot \mathrm{min}^{-}\right.$ $1 \cdot 10^{-6}$ cells). No difference between the two groups was detected in $\mathrm{NADH} \rightarrow$ ferricyanide activity $(0.62$ $\pm 0.24 \mathrm{nmol} \cdot \mathrm{min}^{-1} \cdot 10^{-6}$ cells in IDDM, and $0.73 \pm$ $0.37 \mathrm{nmol} \cdot \min ^{-1} \cdot 10^{-6}$ cells in controls) probably due to the low efficiency of this electron acceptor.

\section{DISCUSSION}

The main underlying metabolic cause of diabetes is the failure of pancreatic beta cells to supply insulin in amounts sufficient to meet the body's requirements, resulting in hyperglycemia. Juvenile (type 1)

Table III

Plasma membrane NADH oxidase activity in lymphocytes (mean values $\pm \mathrm{sd}$ )

\begin{tabular}{|c|c|c|c|}
\hline \multicolumn{2}{|c|}{$\begin{array}{l}\text { Control Subjects } \\
\quad(\mathrm{n}=11)\end{array}$} & \multicolumn{2}{|c|}{$\begin{array}{l}\text { IDDM Patients } \\
\quad(\mathrm{n}=13)\end{array}$} \\
\hline \multicolumn{4}{|c|}{$\left(\mathrm{nmol} \cdot \mathrm{min}^{-1} \cdot 10^{-6}\right.$ cell $)$} \\
\hline $\mathrm{NADH} \rightarrow \mathrm{DCIP}$ & $1.97 \pm 0.51$ & $2.69 \pm 0.59$ & $\mathrm{p}<0.005$ \\
\hline $\mathrm{NADH} \rightarrow \mathrm{K}_{3} \mathrm{Fe}(\mathrm{CN})_{6}$ & $0.73 \pm 0.37$ & $0.62 \pm 0.24$ & $\mathrm{p}=\mathrm{n} . \mathrm{s}$ \\
\hline
\end{tabular}


Fig. 2 - Immunoelectron microscopy of phosphotyrosine in isolated cells at $\left.\mathrm{T}^{0}, \mathrm{~b}\right)$ lymphocytes from IDDM patients treated as control samples. $\mathrm{M}=$ mitochondria. a) cells at $\mathrm{T}^{0}$, b) cells at $\mathrm{T}^{30}$.

diabetes is determined by the immune destruction of beta cells. Adult-onset (type 2) diabetes, which accounts for $90 \%$ of cases of diabetes, is characterised by a partial deficit in insulin production associated with resistance by peripheral tissues to the action of the hormone. Polygenic traits contribute to the pathogenesis of both types of diabetes. However, a specific form of type- 2 diabetes -Mody- is monogenic due to inactivating mutations in genes that are critical for normal beta-cell function 


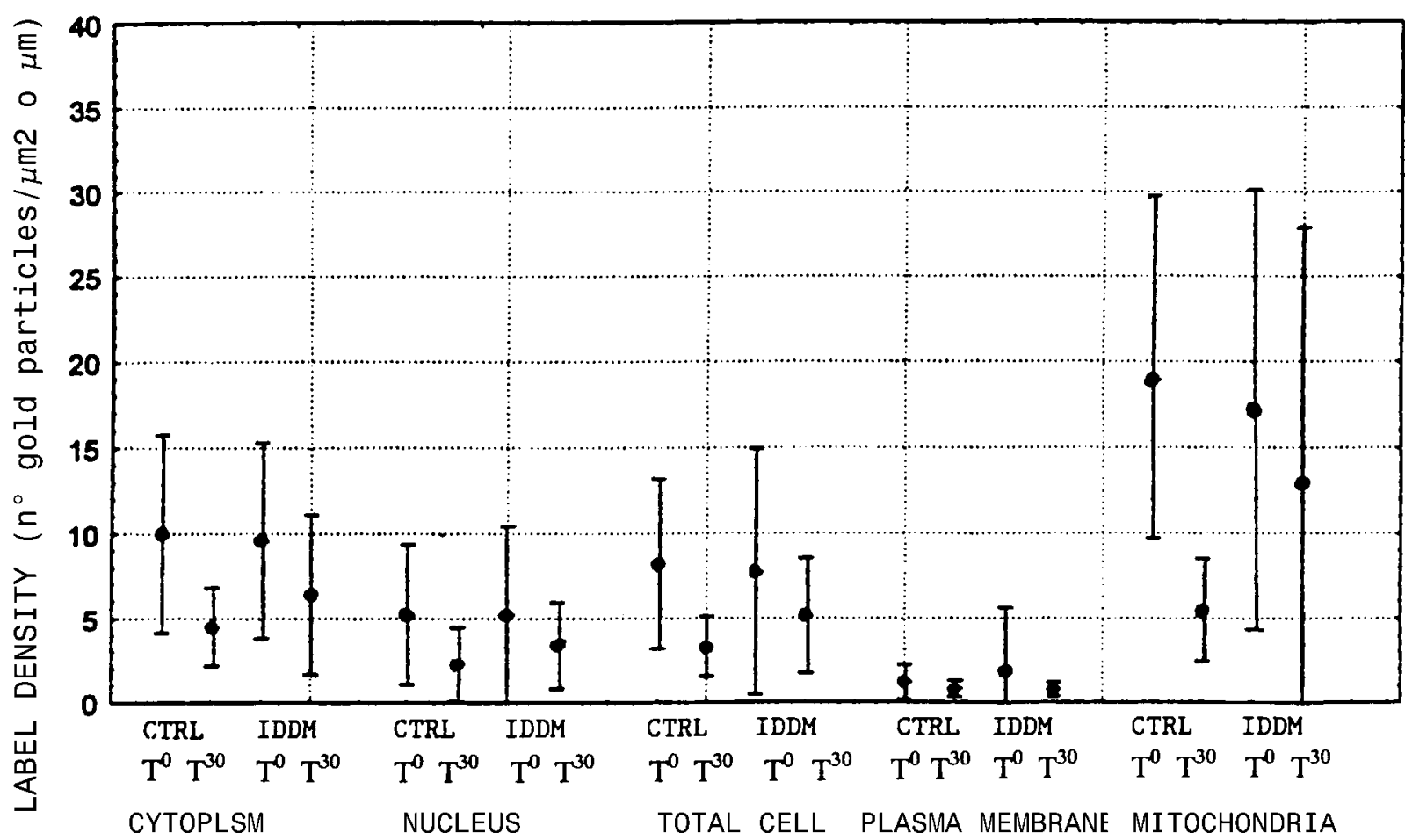

Fig. 3 - Graphic representation of the distribution of morphometric data. High sd values were observed in all cellular districts, mainly in mitochondria. Standard deviations from mean values in control mitochondria at $\mathrm{T}^{0}$ and $\mathrm{T}^{30}$ were not overlapping, with statistically significant differences of the data $(\mathrm{p}<0.05)$.

(Chaturvedi et al. 1997; Rabinovitch et al.1998; Miller et al. 1999).

At the peripheral level, free-radical overproduction contributes to the tissue damage induced by acute hyperglycemia and the administration of molecules with anti-oxidant properties increases tissue resistance to the lipid peroxidation triggered by acute hyperglycemia.

Hyperglycemia may also induce a parallel increase in circulating ICAM through oxidative stress. ICAM is among the most important intercellular adhesion molecules involved in diabetes, even if it is also associated with different pathologies such as atherosclerosis, and it is expressed in activated circulating mononuclear cells, including T cells (Ceriello et al. 1998).

These functional data agree with our findings of higher levels of tyrosine phosphorylation -expression of upregulation- in the lymphocytes of IDDM hyperglycemic patients compared with healthy subjects.

Normal circulating mononuclear cells are known to respond to physiological concentrations of insulin by rapidly increasing the amount of glu- cose that is transported into the cell. The same cells from IDDM insulin-dependent subjects show less capacity for glucose transport both in basal conditions and following insulin stimulation (Estrada et al. 1994).

Insulin stimulates glucose transport via the translocation of the glucose transporters (Glut-1, Glut-3 and Glut-4) from intracellular stores to the plasma membrane. But, for this process to work, an intact actin network and phosphatidyl-inositol 3-kinase activity are necessary (Muller et al. 1998; Kao et al. 1999). Insulin also stimulates autophosphorylation of the insulin receptor on tyrosine (Carter et al. 1996).

Tyrosine phosphorylation at the protein level plays a vital role and is a primary event in signal transduction for the regulation of glucose metabolism (Carter 1996, Pugnaloni et al. 1999). In lymphocytes too, antigens or cytokine receptors induce rapid tyrosine phosphorylation at the level of the receptor subunit, of different membrane proteins and of other signal components that are necessary to maintain a correct functional state in these cells (Saad et al. 1997; Naz 1996; Subrah- 
manyam et al. 1991). In human fibroblasts it has long been known that 50-kDa tyrosine-phosphorylated protein bands can be observed also in purified mitochondria (Piedimonte et al. 1986 ).

Similarly, rat liver mitochondria show protein phosphorylation on specific bands from 47 to 36 kDa (Backer et al. 1986). In spermatozoa, tyrosine phosphorylation has been detected immunocytochemically at the mitochondrial level (Travis et al. 1998).

At the time of collection the tyrosine phosphorylation level was not specifically different in any cellular district of IDDM patients with respect to age-matched controls; however, the morphometric evaluations performed on healthy and IDDM lymphocytes showed that 30 minutes from collection phosphotyrosine levels decreased in all cellular districts possibly as a result of activation of tyrosine phosphatases. This reduction was greater in control lymphocytes, except in the plasma membrane, where the reduction in phosphotyrosine levels was greater in IDDM cells.

In particular at the mitochondrial level, phosphotyrosine values at $\mathrm{T}^{30}$ decreased only marginally in the lymphocytes from IDDM patients, whereas at $\mathrm{T}^{0}$ phosphoprotein values were similar in the two groups of subjects. This finding could be related to the greater activation state of lymphocytes from IDDM patients, more exposed to oxidative-stress stimulation and to altered extracellular-glucose input, maintaining a further steady-state level of tyrosine phosphorylation with time.

It is known that also for lymphocytes, triggering and activation signal-transduction pathways involve tyrosine phosphorylation and dephosphorylation (respectively via kinases and phosphatases).

Several reports, including observations made in our lab (unpublished), are in line with this hypothesis (Hanna et al. 1997; Honeyman et al. 1998). This activation state should be interpreted in the light of biochemical data.

We found indications of a significant derangement of mitochondrial function in the lymphocytes of diabetic patients.

The mitochondrial membrane potential did not appear to be altered in IDDM cells at $\mathrm{T}^{0}$, possibly by virtue of effective respiratory-chain functioning, which usually tends to compensate the membrane potential (unpublished data).

However, the in-vitro addition of increasing concentrations of an uncoupling agent, FCCP, caused a modification in the slope of the regression line, indicating the difficulty of the respiratory chain of diabetic mitochondria to maintain the stationary steady state of the proton electrochemical gradient (D'Aurelio et al. 1998).

The increase in NADH oxidase at the level of the plasma membrane observed in our IDDM lymphocytes is an expression of an increase of cytoplasmic NADH as a result of impaired mitochondrial activity and should be considered as a compensatory mechanism to release excess cytosolic reducing power (Morre et al. 2000). This concept correlates well with i) the presence of an altered plasma micro-environment in IDDM patients, with free radicals stimulating oxidizing activity, and ii) the finding that the redox state of quinone oxidase controls tyrosine kinase via $\mathrm{H}^{2} \mathrm{O}^{2}$ generation or through conformational redox-inducing modifications (Greiber et al. 1998). The plasma membrane of eukaryotic cells contains a NADH oxidase which transfers electrons across the membrane (Morre et al 1998; Van Duijn et al. 1998; Kishi et al. 1999). This oxidase is controlled by hormones (Chueh et al. 1997), growth factors (Morre et al. 1997) and other molecules (Dai et al. 1997) which bind to receptors in the plasma membrane, so it is also linked to the ligand-dependent tyrosine phosphorylation cascade. Oxidants, moreover, activate growth-related signals such as calcium mobilization, while coenzyme-Q analogues reversibly inhibit both growth and transmembrane electron transport (Brightman et al. 1992).

In conclusion, literature data correlate well with the immunohistochemical and biochemical findings of our study, which also seems to point to a possible role for mitochondria as signal transducers in cellular metabolic activities, especially considering the relevance of mitochondrial signals, such as Bax transfer in cytochrome-c release in the signal transduction involved in cell apoptosis (Pedersen, 1999).

Signal transduction may thus represent one of the most easily hit targets in the course of IDDM development.

\section{ACKNOWLEDGMENTS}

The authors are grateful to Prof. Bruno Mannello for his assistance with statistical analysis, graphic representation and data evaluation.

This study was supported by PRIN "Bioenergetics and Membrane transport" from MURST. 


\section{REFERENCES}

Alessandro R., Pugnaloni A., Biagini G., and Kohn E.C.: Regulation of cellular tyrosine phosphorylation by stimulatory and inhibitory muscarinic acetylcholine receptors. Exp. Cell Res. 234, 18-26, 1997.

Backer J.M., Arcoleo J.P., and Weinstein I.B.: Protein phosphorylation in isolated mitochondria and the effects of protein kinase C. FEBS Lett. 200, 161-164, 1986.

Bize I., Munoz P., Canessa M., and Dunham P.B.: Stimulation of membrane serine-threonine phosphatase in erythrocytes by hydrogen peroxide and staurosporine. Am. J. Physiol. 274, C440-6, 1998 .

Brightman A.O., Wang J., Miu R.K., Sun I.L., Barr R., Crane F.L., and Morre D.J.: A growth factor- and hormone-stimulated NADH oxidase from rat liver plasma membrane. Biochim. Biophys. Acta 1105, 109-117, 1992.

Carter W.G., Sullivan A.C., Asamoah K.A., and Sale G.J.: Purification and characterization of an insulin-stimulated insulin receptor serine kinase. Biochemistry 35, 14340-14351, 1996.

Ceriello A., Falleti E., Motz E., Taboga C., Tonutti L., Ezsol Z., Gonano F., and Bartoli E.: Hyperglycemia-induced circulating ICAM-1 increase in diabetes mellitus: the possible role of oxidative stress. Horm. Metab. Res. 30, 146-149, 1998.

Chaturvedi P., Qin H.Y., Chou H., and Singh B.: Modulation of insulin-dependent diabetes mellitus (IDDM) in NOD mice by autoreactive T cells. Crit. Rev. Immunol. 17, 519-528, 1997.

Chueh P.J., Morre D.M., Penel C., De Hahn T., and Morre D.J.: The hormone-responsive NADH oxidase of the plant plasma membrane has properties of a NADH protein disulfide reductase. J. Biol. Chem. 272, 11221-11227, 1997.

Clerk A., Michael A., and Sugden P.H.: Stimulation of multiple mitogen-activated protein kinase sub-families by oxidative stress and phosphorylation of the small heat shock protein, HSP25/27, in neonatal ventricular myocytes. Biochem. J. $1,581-589,1998$

Cobo J.M., and Castineira M.: Oxidative stress, mitochondrial respiration, and glycemic control: clues from chronic supplementation with Cr3+ or As3+ to male Wistar rats. Nutrition $13,965-970,1997$.

Crane F.L., Sun, IL, Crowe R.A., Alcain F.J., and Low H.: Coenzyme Q10, plasma membrane oxidase and growth control. Mol. Aspects Med. 15, S1-S11, 1994.

D’Aurelio M., Sgarbi G., Cavazzoni M., Castelluccio C., Bovina C., Formiggini G., Biagini G., Ragni L., Salardi S., Cacciari E., and Lenaz G.: Alterations of mitochondrial bioenergetics in circulating lymphocytes of IDDM patients.Italian Biochemical Society Transaction 11, 308, 1998.

Dai S., Morre D.J., Geilen C.C., Almond-Roesler B., Orfanos C.E., and Morre D.M.: Inhibition of plasma membrane NADH oxidase activity and growth of HeLa cells by natural and synthetic retinoids. Mol. Cell. Biochem. 166, 101-109, 1997.

Estrada D.E., Elliott E., Zinman B., Poo I., Liu Z., Klip A., and Daneman D.: Regulation of glucose transport and expression of GLUT3 transporters in human circulating mononuclear cells: studies in cells from insulin-dependent diabetic and nondiabetic individuals. Metabolism 43, 591-598, 1994.

Goldkorn T., Balaban N., Matsukuma K., Chea V., Gould R., Last J., Chan C., and Chavez C.: EGF-Receptor phosphorylation and signaling are targeted by $\mathrm{H} 2 \mathrm{O} 2$ redox stress. Am. J. Respir. Cell. Mol. Biol.19, 786-798, 1998.

Greiber S., Munzel T., Kastner S., Muller B., Schollmeyer P., and Pavenstadt H.: NAD(P)H oxidase activity in cultured human podocytes: effects of adenosine triphosphate. Kidney Int. 53, 654-663, 1998 .

Guidarelli A., Brambilla L., Clementi E., Sciorati C., and Cantoni O.: Stimulation of oxygen consumption promotes mitochondrial calcium accumulation, a process associated with, and causally linked to, enhanced formation of tertbutylhydroperoxide-induced DNA single-strand breaks. Exp. Cell. Res. 237, 176-185, 1997.

Hanna A.N., Waldman W.J., Lott J.A., Koesters S.C., Huges A.M., and Thornton D.J.: Increased alkaline phosphatase isoforms in autoimmune diseases. Clin. Chem. 43, 1357-1364, 1997.

Honeyman M.C., Stone N.L., and Harrison L.C.: T-cell epitopes in type 1 diabetes autoantigen tyrosine phosphatase IA2: potential for mimicry with rotavirus and other environmental agents. Mol. Med. 4, 231-239, 1998.

Kao A.W., Noda Y., Johnson J.H., Pessin J.E., and Saltiel A.R.: Aldolase mediates the association of F-actin with the insulin-responsive glucose transporter GLUT4. J. Biol. Chem. 274, 17742-17747, 1999.

Karagezian K.G., Osveplan L.M., and Adonts K.G.: Oxidative processes and phospholipid metabolism in hepatocyte membranes during alloxan diabetes. Vopr. Med. Khim. 36, 10-2, 1990.

Kishi T., Morre D.M., and Morre D.J.: The plasma membrane NADH oxidase of HeLa cells has hydroquinone oxidase activity. Biochim. Biophys. Acta 1412, 66-77, 1999.

Kristal B.S., Koopmans S.J., Jackson C.T., Ikeno Y., Park B.J., and Yu B.P.: Oxidant-mediated repression of mitochondrial transcription in diabetic rats. Free Radic. Biol. Med. 22, 813-822, 1997.

Low P.A., Nickander K.K., and Tritschler H.J.: The roles of oxidative stress and antioxidant treatment in experimental diabetic neuropathy. Diabetes 46, S38-S42, 1997.

Matschinsky, F.M.: Banting Lecture 1995. A lesson in metabolic regulation inspired by the glucokinase glucose sensor paradigm. Diabetes 45, 223-241, 1996.

Matsuoka T., Kajimoto Y., Watada H., Kaneto H., Kishimoto M., Humayahara Y., Fujitani Y., Kamada T., Kavamori R., and Yamasaki Y.: Glycation-dependent, reactive oxygen species-mediated suppression of the insulin gene promoter activity in HIT cells. J. Clin. Invest. 99, 144-150, 1997.

Miller S.P., Anand G.R., Karschnia E.J., Bell G.I., LaPorte 
D.C., and Lange A.J.: Characterization of glucokinase mutations associated with maturity-onset diabetes of the young type 2 ( MODY-2): different glucokinase defects lead to a common phenotype. Diabetes 48, 1645-51, 1999.

Moran A., Zhang H.J., Olson L.K., Harmon J.S., Poitout V., and Robertson R.P: Differentiation of glucose toxicity from beta cell exhaustion during the evolution of defective insulin gene expression in the pancreatic islet cell line, HIT-T15. J. Clin. Invest. 99, 534-539, 1997.

Morigi M., Angioletti S., Imberti B., Donadelli R., Micheletti G., Figliuzzi M., Remuzzi A., Zoja C., and Remuzzi G. Leukocyte-endothelial interaction is augmented by high glucose concentrations and hyperglycemia in a NF-kB-dependent fashion. J. Clin. Invest. 101, 1905-1915, 1998.

Morre D.J., Wu L.Y., and Morre D.M.: Inhibition of NADH oxidase activity and growth of HeLa cells by the antitumor sulfonylurea, N-(4-methylphenylsulfonyl)-N'-(4-chlorophenyl) urea (LY181984) and response to epidermal growth factor Biochim. Biophys. Acta 1355, 114-120, 1997.

Morre D.J., Wu L.Y., and Morre D.M.: Response of a cell-sur face NADH oxidase to the antitumor sulfonylurea $\mathrm{N}-(4$ methylphenylsulfonyl)-N'-(4-chlorophenylurea) (LY181984) modulated by redox. Biochim. Biophys. Acta 1369, 185-192, 1998.

Morre D.M., Lenaz G., and Morre D.J.: Surface oxidase and oxidative stress propagation in aging. J. Exp. Biol. 203(Pt 10), 1513-1521, 2000

Muller G., Rouveyre N., Upshon C., and Bandlow W.: Insulin signaling in the yeast Saccharomyces cerevisiae. 3. Induction of protein phosphorylation by human insulin. Biochemistry 37, 8705-8713, 1998

Naz R.K.: Protein tyrosine phosphorylation and signal trans duction during capacitation-acrosome reaction and zona pellucida binding in human sperm. Arch. Androl. 37, 47-55, 1996.

Novials A., Vidal J., Franco C., Ribera F., Sener A., Malaiosse W.J., and Gomis R.: Mutation in the calcium-binding domain of the mitochondrial glycerophosphate dehydrogenase gene in a family of diabetic subjects. Biochem. Biophys. Res. Commun. 24, 570-572, 1997.

Olson L.K., Qian J., and Poitout V.: Glucose rapidly and reversibly decreases INS-1 cell insulin gene transcription via decrements in STF-1 and $\mathrm{C} 1$ activator transcription factor activity. Mol. Endocrinol. 12, 207-219, 1998.

Pedersen P.L.: Mitochondrial events in the life and death of animal cells: a breif overview. J. Bioenerg. Biom. Vol 31, 291 304, 1999.

Piedimonte G., Silvotti L., Chamaret S., Borghetti A.F., and Montagnier L.: Association of tyrosine protein kinase activity with mitochondria in human fibroblasts. J. Cell. Biochem. 32, $113-123,1986$

Pugnaloni A., Tesei M., Amati S., Mazzanti L., D’Aurelio M., Rabini R.A., Sgarbi G., and Biagini G.: Tyrosine phosphorylation in type-1 diabetes by immunogold detection: an in vitro human aortic endothelial cell (HAEC) study in the presence of diabetic low density lipoproteins. Eur. J. Histochem. 43(3), 199-204, 1999

Rabinovitch A., and Suarez-Pinzon W.L.: Cytokines and their roles in pancreatic islet beta-cell destruction and insulindependent diabetes mellitus. Biochem. Pharmacol. 55, 11391149, 1998.

Ramirez R., Rasschaert J., Sener A., and Malaisse W.J.: The coupling of metabolic to secretory events in pancreatic islets. Glucose-induced changes in mitochondrial redox state. Biochim. Biophys. Acta 1273, 263-267, 1996.

Ramirez, R., Sener, A., and Malaisse, W.J.: Hexose metabolism in pancreatic islets: regulation of the mitochondrial NADH/NAD+ ratio. Biochem. Mol. Med. 55, 1-7, 1995.

Saad M.J., Maeda L., Brenelli S.L., Carvalho C.R., Paiva R.S., and Velloso L.A.: Defects in insulin signal transduction in liver and muscle of pregnant rats. Diabetologia 40, 179186, 1997

Salceda R., Vilchis C., Coffe V., and Hernandez-Munoz R.: Changes in the redox state in the retina and brain during the onset of diabetes in rats. Neurochem. Res. 23, 893-897, 1998.

Subrahmanyam G., Bertics P.J., and Anderson R.A.: Phosphorylation of protein 4.1 on tyrosine- 418 modulates its function in vitro. Proc. Natl. Acad. Sci. USA 88, 5222-5226, 1991.

Travis A.J., Foster J.A., Rosenbaum N.A., Visconti P.E., Gerton G.L., Kopf G.S., and Moss S.B.: Targeting of a germ cellspecific type 1 hexokinase lacking a porin-binding domain to the mitochondria as well as to the head and fibrous sheath of murine spermatozoa. Mol. Biol. Cell. 9, 263-276, 1998.

Vaillant F., Larm J.A., McMullen G.L., Wolvetang E.J., and Lawen A.: Effectors of the mammalian plasma membrane NADH-oxidoreductase system. Short-chain ubiquinone analogues as potent stimulators. J. Bioenerg. Biomembr. 28, 531540,1996

Van Duijn M.M., Van der Zee J., Van Steveninck J., and Van den Broek P.J.A.: Ascorbate stimulates ferricyanide reduction in HL-60 cells through a mechanism distinct from the NADH-dependent plasma membrane reductase. J. Biol. Chem. 273, 13415-13420, 1998

Victor T., Van der Merwe N., Benade A.J., La Lock C., and Lochner A.: Mitochondrial phospholipid composition and microviscosity in myocardial ischaemia. Biochim. Biophys. Acta 834, 215-223, 1985.

Vidal J., Corominola H., Cardona F., Levy I., Cararach V., Gomis R., and Malaisse W.J.: Low mitochondrial glycerophosphate dehydrogenase activity in lymphocytes of women with gestational diabetes. Horm. Met. Res. 29, 60-62, 1997. 